Sultan Qaboos University Journal of Arts \& Social Science

جامعة السلطان قابوس مجلة الآداب والعلوم الاجتماعية

\title{
THE METONYMIC FUNCTIONS OF THE VERB FA?ALA IN THE HOLY QUR'AN
}

\begin{tabular}{c}
\hline Abdul Gabbar Al-Sharafi \\
\hline English Department \\
College of Arts \& Social Science \\
Sultan Qaboos University \\
alsharaf@squ.edu.om
\end{tabular}




\title{
The Metonymic Functions of the Verb fa?ala in the Holy Qur'an
}

\begin{abstract}
Abdul Gabbar Al-Sharafi
Abstract: This study builds on an observation that the verb fa?ala in Arabic, which means 'do', is essentially metonymic; it can refer to any transitive or intransitive verb in the language. This referential function is paradigmatic in nature and has been mentioned by classical Arab grammarians, hence their choice of this verb as the template or pattern on which all action verbs are formulated and modulated. The study proceeds from this basic observation to propose another type of referential function of the verb fa?ala, which is syntagmatic in nature: the cohesive function. Taking the Holy Qur'an as the corpus for this study, both functions of the verb are investigated in this study. A statistical analysis is carried out to identify all the occurrences of the verb fa?ala and its derivatives in the Holy Qur'an within their textual contexts, usually the verse. A textual analysis of each of these occurrences is, then, carried out to reveal the metonymic function of the verb fa?ala in all these instances. The study shows that within the general metonymic referential function of the verb fa?ala two basic sub-functions can be identified. The first is plain reference and the second is euphemistic reference. The findings of this study show that the plain reference function only accounts for about $37 \%$ of the total occurrences, while the euphemistic reference accounts for about $63 \%$ of the total Holy Qur'an corpus. These findings are significant because no previous study has addressed this textual aspect of the verb fa?ala in the Holy Qur'an, not even classical and contemporary exegetes. This study is also significant to linguistic and figurative studies of the Holy Qur'an, Holy Qur'an corpus studies and textual and pragmatic analysis of the Holy Qur'an.
\end{abstract}

Key Words: Metonymy, cohesion, euphemism, representation, referential metonymy, social stigma, taboo.

\section{الوظائف الكنائية للفعل (فعل) في القرآن الكريم}

عبدالجبار محمد الشرفي

مستخلص: ينبني هذا البحث على فكرة أن الفعل (فعل) في اللغة العربية هو في الأساس فعل كنائي، بمعنى أنه يمكن أن يشير إلى أي فعل

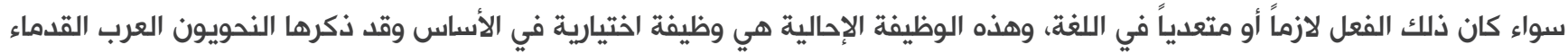

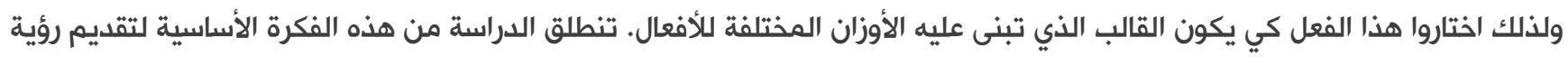

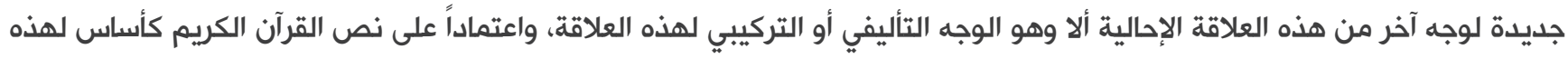

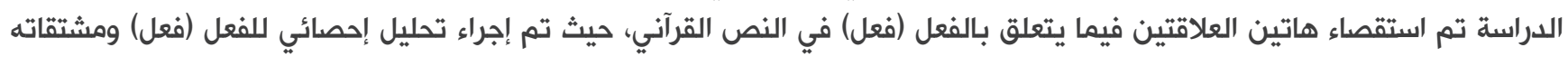

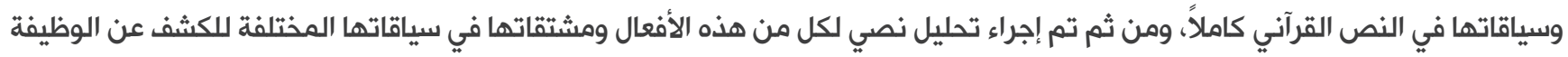

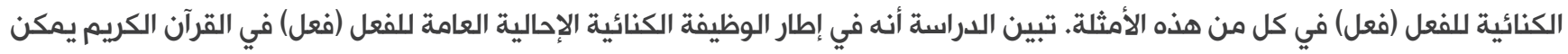

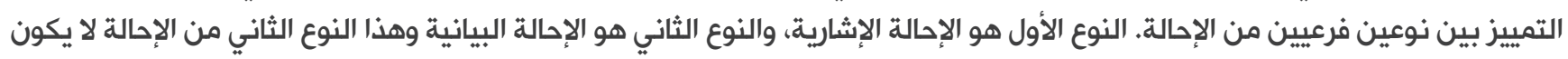

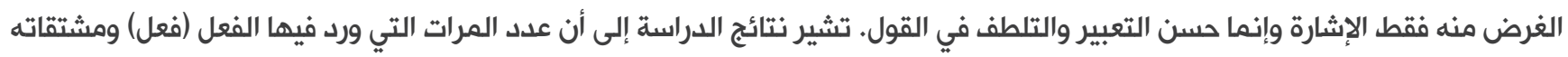

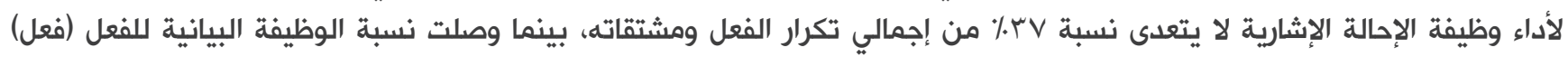

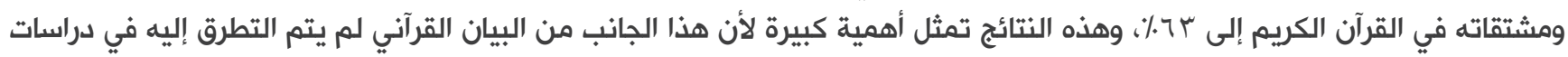

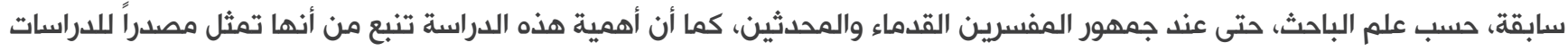

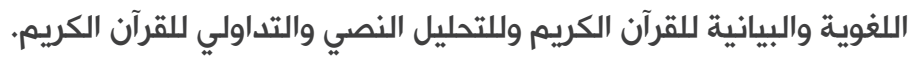
الكلمات الدالة : الكناية، الترابط النصي، التلطف في التعبير، التمثيل، الكناية الإحالية، الوصمة الاجتماعية، العيب . 


\section{INTRODUCTION}

This study stems from a basic observation that the verb fa?ala in Arabic is metonymic in nature. It is metonymic on the selectional systemic level because it can substitute any action verb in the language. Itisalsometonymiconthecombinatorial level because it performs a cohesive function. In both capacities, it makes use of its substitutional power to perform a representational role. This substitutional characteristic of the verb fa?ala and the referential relationship between the verb fa?ala and its referent deserves to be investigated and discussed in light of a textual corpus. Such a corpus study is particularly significant when the corpus is the Holy Qur'an as this will shed new light on the semantics and pragmatics of the Holy Qur'an, an area which is poorly served in current linguistic studies of the Holy Qur'an.

\section{The metonymic basis of the verb fa?ala}

Metonymy is generally defined as a figure of speech in which the name of one thing is used for that of another with which it is associated, or for which it is an attribute. For example, the word 'crown' in expressions like 'lands belonging to the crown' in which the word crown means the monarch. In figurative terms, we can say that the strong association between 'the monarch' and 'the crown' makes it possible to use 'the crown' to represent 'the monarch'. In cognitive terms, we can say that both 'monarch' and 'crown' are cognitively contiguous, i.e. adjacent, one next to the other to the extent that one can conjure the other because together they form a coherent conceptual structure.

Ferdinand de Saussure (1983) argues that there are two modes of linguistic signification: one is paradigmatic (vertical) and the other is syntagmatic (horizontal). The first is essentially selectional in which the language user selects from the vertical axis of the language store between elements of the same system and the second is combinational in which the language user strings together on the horizontal axis of the language to make discourse or structure.

Jakobson (1971) attempts to map these two modes of representation onto two modes of figurative language: metaphor and metonymy respectively. He argues that metaphor is essentially paradigmatic and metonymy is essentially syntagmatic because metaphor is based on a relation of equivalence and choice; whereas metonymy is based on a relation of contiguity and combination. In other words, metaphor is based on a relation of resemblance between two or more objects, i.e. an endless inventory of resemblances between Juliet and the sun in the famous Shakespearean quote "Juliet is the sun" in Romeo and Juliet. Metonymy on the other hand, is based on the principle of contiguity, i.e. part/whole, whole/part, part/part and cause/ effect relations among other relations of this kind. The word 'keels' in the famous quote 'fifty keels ploughed the deep' is not similar to a ship but it is part of it.

In this paper, it is argued that with regard to its referential function, the verb fa?ala has both a paradigmatic and a syntagmatic reference. The verb fa?ala enters into paradigmatic relationship with any potential action verb in the language because it can potentially substitute that verb in any linguistic environment; every action verb is fi?l. It can also enter into syntagmatic relationship with any action verb in the language because it can potentially substitute that verb on the horizontal axis if there is need to refer again to that verb in the discourse. 
Current accounts of metonymy are cognitive in nature. A major assumption among cognitive linguists is that knowledge is organized in conceptual structures. These have been named differently by different people: domains by (Lakoff and Johnson, 1980) and (Croft, 1993), mental spaces (Fauconnier, 1985), idealized cognitive models ICMs (Lakoff, 1987), conceptual blends (Fauconnier, 2002). Metonymy is seen to be one of the main mechanisms of organizing such knowledge by establishing relations of association between elements of these structures (cf. AlSharafi, 2004).

\section{The paradigmatic reference of the verb fa?ala}

Classical Arab lexicographers and exegetes have alluded to the metonymic function of the verb fa?ala in its paradigmatic aspect. This is to say that these accounts take the verb fa?ala as a linguistic item that can refer paradigmatically to the entire system of transitive and intransitive action verbs in Arabic. Two of these accounts are presented here:

In his lexixon, Lisaan Al-Arab "The Arab Tongue", the classical Arabic lexicographer, Ibn Manzour (1999, p. 292) defines the verb fa?ala as 'a kinaayah 'metonymy' of every action verb, transitive or intransitive. The Arabs form patterns on the verb fa?ala and Ibn Jinni used the metonymic verb fa?ala to map poetic meter and feet system.'(1) In his lexicon, Taaj Al Araoos "The Crown of the Bride", Al-Zabeedi (2007, pp. 104 -105), another classical Arabic lexicographer defines the verb fa?ala as 'a verb that can be used to metonymically express any action whether transitive or intransitive. The Arabs used this verb metonymically to make their awzaan 'patterns' of grammatical forms. They also used it to make prosodic patterns of poetry.'

\section{The syntagmatic reference of the verb fa?ala}

In his rhetorically-based Holy Qur'an exegesis, Al-Kashshaaf "The Revealer", the Holy Qur'an exegete Al-Zamakhshari(2) comments on the substitution of the verb 'produce' in the verse:

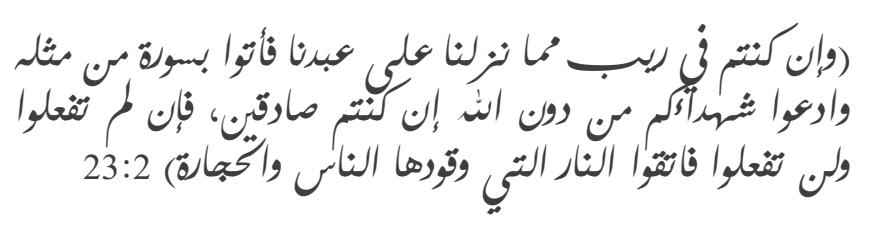

PICKTHAL(3) : And if ye are in doubt concerning that which We reveal unto Our slave (Muhammad), then produce a surah of the like thereof, and call your witness beside Allah if ye are truthful. And if ye do it not - and ye can never do it - then guard yourselves against the Fire prepared for disbelievers, whose fuel is of men and stones.

Al-Zamakhshari's comment runs as follows: 'if you say why the verb 'produce' is replaced by the verb 'do' and what is the point in leaving out the original verb? I say: this is because the verb "do" is a metonymy for all verbs, you say I went to $X$ and it is said to you: good what you did". The advantage of this use is that 'do' functions metonymically giving you the shortest distance to understanding and interpretation and reduces

1. Unless otherwise indicated, all the translations from classical sources throughout this paper are my own translations.

2. All references to Al-Zamakhshariss comments included in this paper are taken from his exegesis published in the official website of the Royal Aal Al-Bayt Institute for Islamic Thought at http://www.altafsir.com

3. All references to Pickthalss translations included in this paper are taken from his translation published in the official website of the Royal Aal Al-Bayt Institute for Islamic Thought at http://www.altafsir.com 
the length of the original element substituted.'

Al-Zamakhshari's account here is a clear statement of the syntagmatic (textual) function of the verb fa?ala as it shortens distances, avoids repetition of antecedents and binds the text making it stand as a unified whole by establishing textual cohesion.

Al-Sharafi (2004, p. 1) provides a semiotic definition of metonymy as 'a process of representation in which one item stands for another by contiguity or causality'. Based on this definition, he proposes a textual approach to metonymy as a text binding trope. On the basis of his textual approach, the Arabic verb fa?ala can be seen as performing a (horizontal) "stand for" relationship with its referent on the basis of contiguity or causality, establishing a unique cohesive relation between textual elements in the Qur'anic text. By contiguity is meant those associations which bring the verb fa?ala and its referent into relations of textual or contextual proximity.

By causality is meant that the association is motivated by social or personal motivation and once this motivation is construed the textual relation is established and justified. It is clear from examples (1) and (2) below that there is a referential relationship between the verb atfa'ta 'switched off' and the verb fa?altu 'did' in (1) and the verb katabtu and the verb fa?altu in (2). This referential relationship is documented in English (cf. Halliday and Hassan, 1976) and Harweg (1977) as 'substitution' and is referred to in Arabic as 'istibdaal' (cf. KhaTTaabi, 1991).

(1)A: hal atfa'ta an noor?

(Did you switch off the light?)

B: na?am fa?altu.

(Yes, I did)

(2)A: laqad katabtu risaalatan ila al mudiiri
(I have written a letter to the manager)

B: wa'ana fa?altu thaalika 'ayDan

(I did that too)

In example (1), the relation is that of textual proximity because the textual distance between the verb fa?altu and its antecedent aTfa'ta is short enough to retrieve and establish a cohesive tie (cf. Halliday and Hassan, 1976) between the two elements. In example (2), the same textual relation holds between the verb fa?altu and its antecedent katabtu. This association can also be contextual, i.e. the referent is retrievable from the context of situation or the context of culture as evident in the 'monarch' and 'crown' example discussed above.

Stirling (1996, p. 70) defines metonymy as 'a semantico-cognitive link between two uses of a lexical item grounded in a relation of association between the things designated in each use'. She argues that a significant number of 'indirect anaphora' involve 'what would be classified independently as a metonymical connection between the anaphor and some expression in the preceding discourse' (ibid). Stirling shows the metonymical connections between anaphoric expressions and the antecedent discourse.

The Arabic verb fa?ala is, therefore, essentially metonymic in the sense that it can replace any process or action verb, and this substitutional power is possible due to an underlying association which enables the verb fa?ala to represent all other process and action verbs in the language, hence establishing a representational relationship between the verb fa?ala and the substituted verb. Metonymically, we can show this paradigmatic and syntagmatic interrelation as follows: 


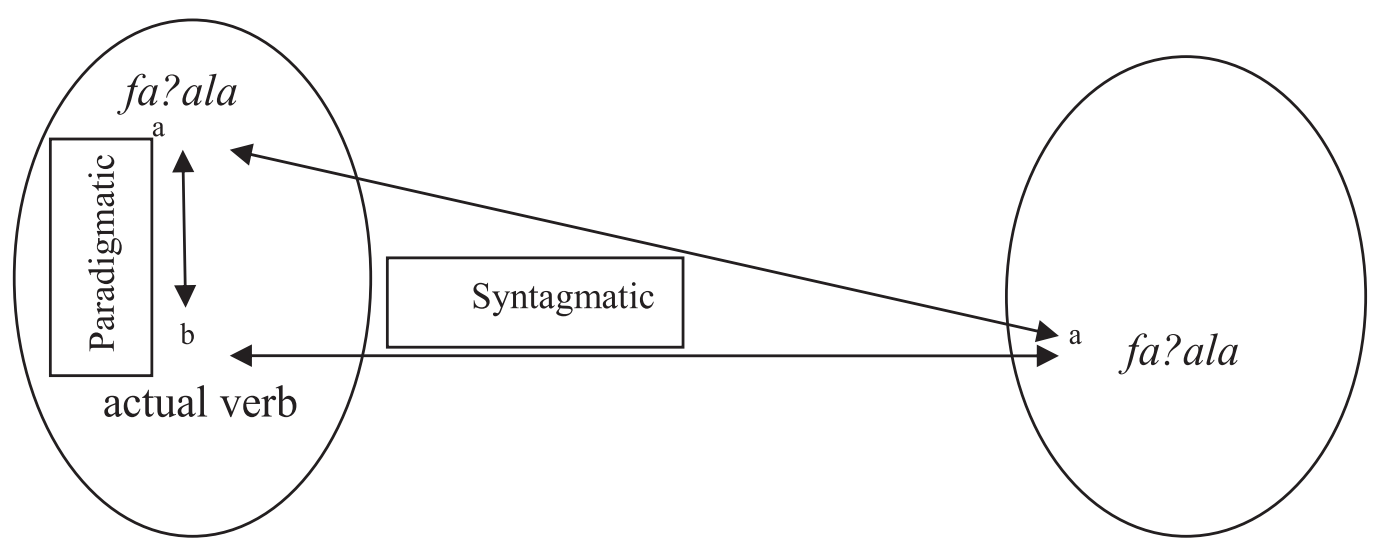

Diagram (1) The interrelation between the paradigmatic relations and the syntagmatic relations of the verb fa?ala

The verb fa?ala in its triliteral root form was identified as the target of the Holy Qur'an corpus analysis. Abdul Baqi's (2004) Indexed Dictionary of the Words of the Holy Qur'an was used to identify all the occurrences of the verb fa?ala and its derivatives in the Qur'anic text. The root of the verb fa?ala was searched in all chapters of the Holy Qur'an. The particular verse in which the verb fa?ala occurs was extracted and written in full in the body of this paper as shown in the discussion and analysis section below. If the antecedent of the verb fa?ala is also present in the same verse, then the sample is restricted to that verse. But if the antecedent of the verb fa? ala is mentioned in another preceding verse, then this verse was also presented to make it easy to refer to the two elements of the cohesive tie. If the distance is too far, ten verses or more, then a short comment specifying the link is given. Sometimes the link is contextual or generic, i.e. there is no textual antecedent. In this case, a short note is provided to clarify the point. The Arabic version of the Qur'anic text is given in the analysis and discussion section below along with an English translation by Marmaduke Pickthal.(1)

For the exegesis of the Qur'anic verses AlZamakhashri's Kashshaaf is used because it is known among scholars of Holy Qur'an exegesis to be a rhetorically based exegesis. It is expected to address some of these figurative aspects of the verb fa?ala in the Holy Qur'an and reveal some common concerns shared with the remit of this study. The systematic search showed all such occurrences in addition to some occurrences of certain derivatives of the verb like the active participle faa?il in addition to the various forms of the verb fa?ala when they display various grammatical categories like tense, gender, person, number, mood and voice. The passive participle maf?uul was excluded from the corpus because it does not really denote a verbal function with an argument structure. The classification of the two main types of reference, i.e. the plain reference and the euphemistic reference, identified in this corpus analysis was based on a distinction between two main categories of reference. The first one is that in which the referential relation is characterized by

1. Pickthal's translations and Al-Zamakhshari's commentaries on the verses provided in this study are taken from the Royal Aal Al-Bait Institute for Islamic Thought website www.altafsir.com 
a neutral or positive sense denoted by the main verb to which the verb fa?ala refers. This type is, therefore, called 'plain reference'. For example, the reference in the following verse is considered plain reference because the sense expressed by the main verb is positive, i.e. 'enjoins almsgiving and kindness and peace-making' so there is no need for euphemism. In this and similar examples the verb fa?ala has a purely referential function.

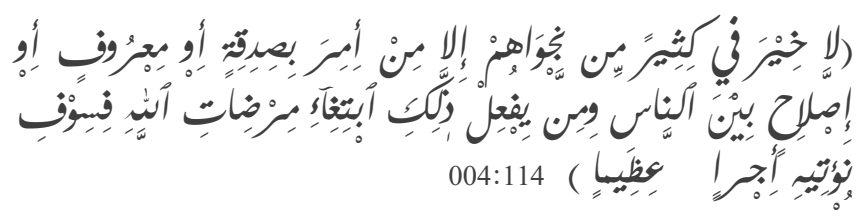

PICKTHAL: There is no good in much of their secret conferences save (in) him who enjoineth almsgiving and kindness and peace-making among the people. Whoso doeth that, seeking the good pleasure of Allah, We shall bestow on him a vast reward.

The second category of reference is that which realizes a relationship between a main verb which expresses a taboo or negative sense and the verb fa?ala. In this case, the relationship between the two verbs is classified as euphemistic reference. For example, in the following verse the reference is interpreted as euphemistic.

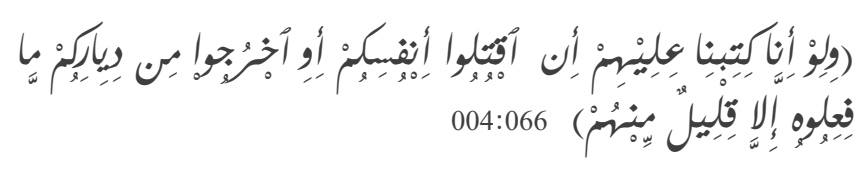

PICKTHAL: And if We had decreed for them: Lay down your lives or go forth from your dwellings, but few of them would have done it;

Here the verb phrase 'would have done' refers back to 'lay down your lives or go forth from your dwellings' and this is considered a euphemistic reference because the verb fa?ala refers to expressions of killing and some sort of punishment by means of forced migration. These expressions are not repeated but a euphemistic form of reference using the verb fa?ala, which is a metonymic form of all verbs, is used to refer to this somehow unfavorable expression. The relationship between the main verb and the verb fa?ala used to substitute it is seen as euphemistic aiming to avoid explicit expression of that sense of the verb in question.

\subsection{Results of corpus analysis}

The systematic search and analysis of the verb fa?ala in the Holy Qur'an shows the statistics shown in table (1)

All of the 101 occurrences display a referential function whether paradigmatic or syntagmatic. Within this broad category of referential metonymy, there are two subcategories:

\subsubsection{Plain reference}

37 occurrences are classified as plain reference because they refer to either neutral or positive senses. This makes about $37 \%$ of the entire corpus, and is divided into the following textual categories:

\section{(A)Endophoric reference}

There are 12 occurrences of this reference whose antecedent is retrievable from the surrounding text and it is divided into two sub-categories:

(1)Anaphoric reference: 12 occurrences.

(2)Cataphoric reference: 2 occurrences

These two occurrences actually belong to the euphemistic reference, so they are not counted and this category is surrounded with brackets in the diagram below).

\section{(B)Exophoric reference}

There are 25 occurrences of this reference whose antecedent is not retrievable from the surrounding text but rather from the surrounding context, 
whether context of situation or generic context. The 25 occurrences of exophoric reference are divided into the following two categories:

(1)Contextual reference: 8 occurrences.

(2)Generic reference: 17 occurrences.

\subsubsection{Euphemistic reference}

64 occurrences are classified as euphemistic reference on the basis of the principle mentioned earlier. This makes about $63 \%$ of the total corpus. These occurrences cover the following categories: (A)Reference to sin: 62 occurrences covering the following types:

(1)Expressions of harm, 26 occurrences

(2)Expressions of injustice, 2 occurrences

(3)Expressions of blasphemy, 32

occurrences

(4)Expressions of indecency, 2 occurrences (B)Reference to social stigma, 2 occurrences

\section{Data analysis and discussion}

Diagram (2) below shows the basic metonymic function of the verb fa?ala in the Holy Qur'an; the referential function, and its two basic sub-

\begin{tabular}{|c|c|c|c|c|}
\hline No & Verb & Transcription & Translation & $\begin{array}{c}\text { No of } \\
\text { Occurrences }\end{array}$ \\
\hline 1 & يفعل & Yaf?alu & He does & 18 \\
\hline 2 & يفعلون & Yaf?aluun & They do (masculine) & 15 \\
\hline 3 & فعل & Fa?ala & He did & 9 \\
\hline 4 & تفعلوا & Taf?aluu & You do (plural masculine subjunctive) & 9 \\
\hline 5 & فاعلين & Faa?iliin & Doers (masculine accusative) & 6 \\
\hline 6 & تفعلون & Taf?aluun & You do (plural masculine indicative) & 6 \\
\hline 7 & فعلوه & Fa?aluuhu & They did it (masculine) & 5 \\
\hline 8 & فعلوا & Fa?alauu & They did (masculine) & 4 \\
\hline 9 & فعلت & Fa?alta & You did (singular masculine) & 4 \\
\hline 10 & نفعل & Naf?alu & We do & 3 \\
\hline 11 & فاعلون & Faa?iluun & Doers (masculine nominative) & 3 \\
\hline 12 & افعلوا & If?aluu & Do (plural masculine) & 2 \\
\hline 13 & فعلن & Fa?alna & They did (feminine) & 2 \\
\hline 14 & فعال & Fa??aal & Doer (masculine) & 2 \\
\hline 15 & فعلتم & Fa?altum & You did (plural masculine) & 2 \\
\hline 16 & يفعلوا & Yaf?aluu & They do (masculine) & 2 \\
\hline 17 & فعلنا & Fa?alnaa & We did & 1 \\
\hline 18 & فعله & Fa?alahu & He did it & 1 \\
\hline 19 & فعلتك & Fa?lataka & Your deed & 1 \\
\hline 20 & فعلتها & Fa?altuhaa & I did it & 1 \\
\hline 21 & افعل & If?al & Do (singular masculine) & 1 \\
\hline 22 & يفعله & Yaf?aluhu & He does it & 1 \\
\hline 23 & تفعلوه & Taf?aluuhu & You do it (plural masculine) & 1 \\
\hline 24 & فاعل & Faa?il & Doer (masculine) & 1 \\
\hline 25 & تفعل & Taf?alu & You do (singular masculine) & 1 \\
\hline \multicolumn{4}{|c|}{ Total Occurrences } & 101 \\
\hline
\end{tabular}

Table (1) Results of statistical analysis of the occurrences of the verb fa?ala in the Holy Qur'an 


\section{Metonymic Functions of the verb fa? ala in the Holy Qur'an}

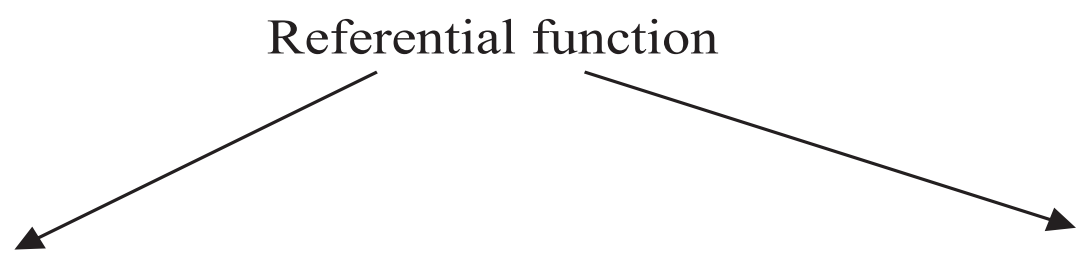

\section{Plain reference}

Euphemistic reference

Diagram (2) The basic metonymic function of the verb fa?ala in the Holy Qur'an and its two subfunctions

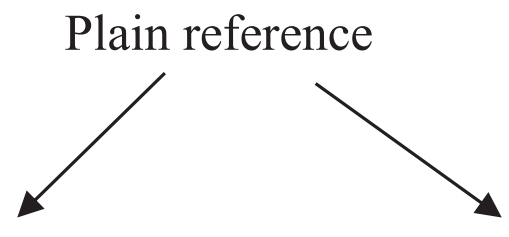

Endophoric reference

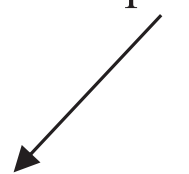

Anaphoric

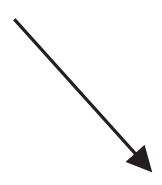

(Cataphoric)

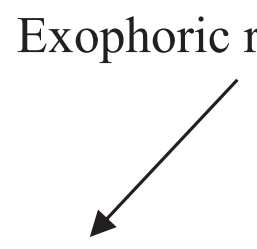

Generic

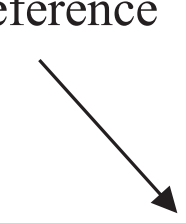

Contextual

Diagram (3) The two main types and sub-types of plain reference metonymy of the verb fa?ala in the Holy Qur'an

types: the plain reference and the euphemistic reference.

The referential function of the verb fa?ala is found to be the major metonymic function of this verb. It is subdivided into two main types of reference: plain reference and euphemistic reference.

\subsection{Patterns of plain reference}

Plain reference is the type of reference which exits between two or more elements for the sake of establishing a relation of identity of reference or coreference, thus establishing a cohesive tie or a cohesive chain and providing texture to the text (Halliday and Hasan, 1976). The textual function is overriding in this type of reference as the aim is to establish cohesion and make the text a unified whole. This type of reference is not used to ornate or hide an explicit expression that may offend or cause embarrassment to anyone. Two main categories of plain reference can be identified as the diagram shows. The first is endophoric reference which is the inward reference, i.e. the text refers to items mentioned somewhere in the same text either before or after the referring item. If the reference is to an item mentioned before it is backward or anaphoric reference. If the reference is to an item mentioned after it is called forward or cataphoric reference.

The second type of plain reference is exophoric reference, and here the reference is outward, i.e. 
outside the text either in the context of situtaion or in the potential reference of the paradigmatic axis of language representation (generic). In the case of the former the reference is called contextual and in the case of the latter it is generic. The following four examples are representative of the four different types of reference.

\section{(1) Anaphoric reference}

Anaphoric reference is a relation between two textual elements where the antecedent precedes the referring item and the reference relation operates backward. This is the most common form of textual reference and the most basic text binding relation that holds the text together as a unified whole. In this section, I will discuss two examples of anaphoric reference of the verb fa?ala in the Holy Qur'an. Of course it will not be feasible in this paper to discuss all the examples of anaphoric reference of the verb fa?ala in the Holy Qur'an or any other type of reference for that matter. The entire list of all such examples is provided in appendix (1). One example of this type of relation is found in the following verse from chapter 002.

AL-BAQARAH 'The Cow' - 002.067-68

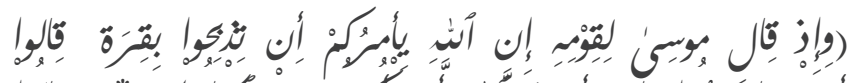

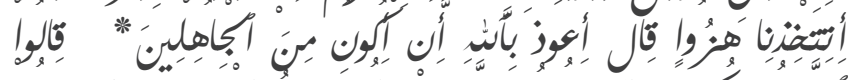

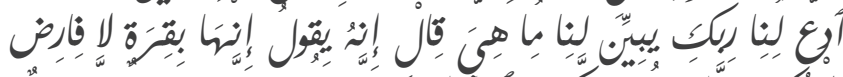

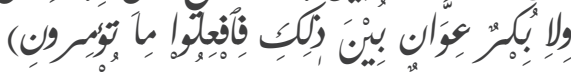

PICKTHAL : And when Moses said unto his people: Lo! Allah commandeth you that ye sacrifice a cow, they said: Dost thou make game of us ? He answered: Allah forbid that I should be among the foolish! They said: Pray for us unto thy Lord that He make clear to us what (cow) she is. (Moses) answered: Lo! He saith, Verily she is a cow neither with calf nor immature; (she is) between the two conditions; so do that which ye are commanded.
The verb fa?ala appears here in its imperative form with the 2 nd person plural suffix. The command is from Allah to the people of Moses ordering them to slaughter a cow. In this case, the verb fa?ala refers backward to its referent which 'slaughter'. This is an example of anaphoric reference that creates a cohesive tie between two elements in the same text, in this case the Qur'anic verse. It can be argued here that there is a euphemistic element in this referential relation as the verb fa?ala in this verse actually refers to an act of killing or slaughtering of a cow. However, it should be noted that this act of killing is contextually desirable because it is an offer of sacrifice to Allah, hence the Arabic verb 'kill' is successfully rendered by Pickthal as 'sacrifice'. This rendition captures the positive and desirable aspect of the action. For this reason, I consider the verb fa?ala in this particular verse an example of plain reference, rather than euphemistic reference.

Another example is from chapter 005 'The Table Spread'

AL MAA'IDAH 'The Table Spread' 005:067

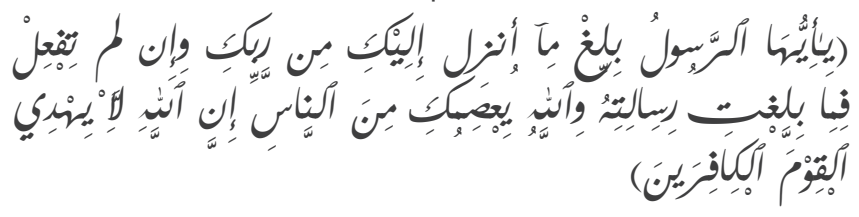

PICKTHAL: O Messenger! Make known that which hath been revealed unto thee from thy Lord, for if thou do it not, thou wilt not have conveyed His message. Allah will protect thee from mankind. Lo! Allah guideth not the disbelieving folk.

It is perfectly possible to repeat the verb phrase 'make known that which has been revealed unto thee from thy Lord'. However, the verb fa?ala is used instead to shorten distances in communication, help the language user to avoid 
repetition and bind the text together as a unified whole. Also because the verb fa?ala refers back to a neutral action which is that of conveying or making known the revelation, this relationship is considered purely referential, i.e. there is no need to hide an offensive expression in this case, so the reference is not euphemistic. It is plain reference that ensures effective communication and pithy style.

\section{(2) Cataphoric reference}

Cataphoric reference is that kind of textual relation that exists between two linguistic items; one is called the referring item and it precedes the other which is known as the referent, hence the referring relation is that of forward nature. The referring item anticipates the referent creating this kind of textual dependency relationship. There are two examples of cataphoric reference established by the verb fa?al in the Holy Qur'an. One is in chapter 89 'The Dawn' and the other is in chapter 105 'The Elephant'. However, the nature of reference of the verb fa?ala in these two occurrences is euphemistic because it substitutes an expression of harm and punishment. Therefore, these two examples will be discussed under euphemistic reference and the node 'cataphoric' in the diagram above is represented with brackets showing that there are no examples of plain cataphoric reference of the verb fa?ala in the Holy Qur'an.

\section{(3) Contextual reference}

Two features make this type of reference distinct from other types of plain reference. First it is paradigmatic, and this means that it does not specifically refer to an item mentioned before or after. It refers to the potential referential feature of the verb fa?ala to refer to any action. Second this type of reference is specified by the context which limits its scope of application to actions that are generally good and refer specifically to a particular context. Two examples will be given to illustrate this type of reference. The example below is from chapter 002 'The Cow'.

AL-BAQARAH 'The Cow' 002.197

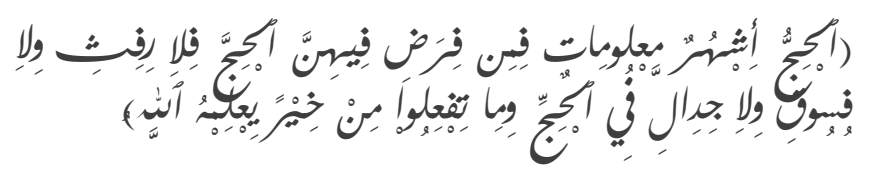

PICKTHAL: The pilgrimage is (in) the well-known months, and whoever is minded to perform the pilgrimage therein (let him remember that) there is (to be) no lewdness nor abuse nor angry conversation on the pilgrimage. And whatsoever good ye do Allah knoweth it.

Here the verb taf?aluu does not really refer back to the set of deeds mentioned earlier which should not be done during pilgrimage such as lewdness or abuse and so on. Rather it refers to a specific context, i.e. that of hajj 'pilgrimage'. This involves a specified set of actions that pilgrims are advised to perform during this religious occasion. The word 'good' is the trigger to this textual specification. It refers not to any action but to those good deeds that should replace those bad deeds mentioned earlier. Various interpretations of the verb phrase 'whatever good ye do' exist. Some exegetes such as, Al Zamakhshari, suggests that the verse commands pilgrims to replace all those bad deeds with good deeds. He also thinks that the good they are advised to do is to control themselves not to do those bad deeds during pilgrimage. These explanations show that the referential verb fa?ala here refers to a contextually bound referent.

Another example of contextual reference is the following from chapter 004 'Women'

AL-NISAA' 'Women' 004:127 


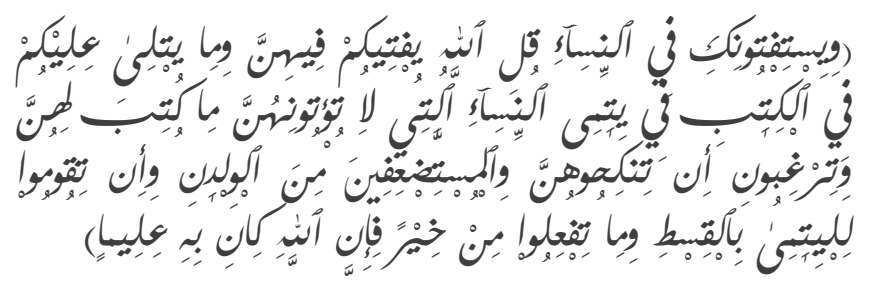

PICKTHAL: They consult thee concerning women. Say: Allah giveth you decree concerning them, and the Scripture which hath been recited unto you (giveth decree), concerning female orphans and those unto whom ye give not that which is ordained for them though ye desire to marry them, and (concerning) the weak among children, and that ye should deal justly with orphans. Whatever good ye do, lo! Allah is ever Aware of it.

Young orphans are normally assigned to a guardian who looks after them and their inheritance (wealth). The verb fa?ala here is restricted by the word 'good' and the context of dealing with orphans particularly female orphans. The reference is to any fair treatment legal guardians are commanded to do to these orphans. Whatever good to be done to these orphan women will be counted and recorded and those legal guardians who do it will be rewarded for it. The word 'good' is a textual cue to a particular context of doing 'good'. In addition to this, the particular context of 'dealing with orphans - female orphans' is a contextual cue. Both the textual cue and contextual cue guide the reader toward a contextual interpretation of this kind of reference.

\section{(4) Generic reference}

This type of reference is similar in one respect to the contextual reference discussed in section (3) above in that the reference does not really indicate a previous or following item, i.e. it is paradigmatic not syntagmatic. However, generic reference differs from contextual reference in that there is no particular context that limits the scope of reference like the context of 'pilgrimage' and 'dealing with orphans' in the two previous examples respectively. Here the reference is generic as it refers to Allah's ability and willingness to do whatever He wants or wills. The reference is generic because the potential of paradigmatic referentiality is open-ended. It could cover the actions mentioned in the verbs mentioned earlier but could equally refer to any action of reward or punishment that Allah can do. The following two examples show this kind of reference in more detail. The first example is from chapter 002.

AL-BAQARAH 'The Cow' 002.253

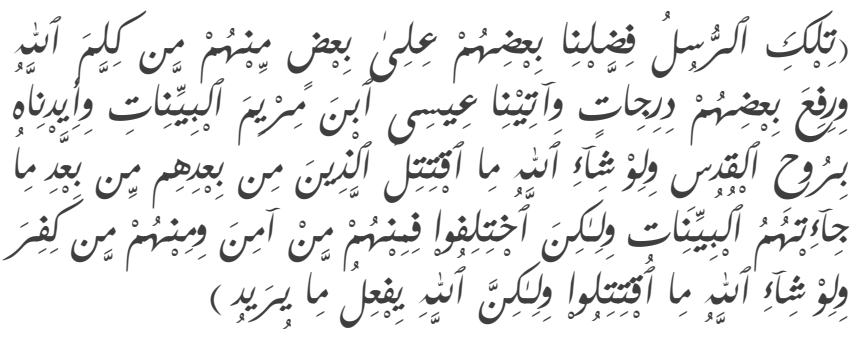

PICKTHAL: Of those messengers, some of whom We have caused to excel others, and of whom there are some unto whom Allah spake, while some of them He exalted (above others) in degree; and We gave Jesus, son of Mary, clear proofs (of Allah's Sovereignty) and We supported him with the holy Spirit. And if Allah had so wiled it, those who followed after them would not have fought one with another after the clear proofs had come unto them. But they differed, some of them believing and some disbelieving. And if Allah had so willed it, they would not have fought one with another; but Allah doeth what He will.

It could be argued that the verb fa? ala in this verse refers to the action of 'fighting' mentioned earlier in the verse. But according to Al Zamakhshari, the verb fa?ala actually refers to all sets of actions that relate to disenchantment or protection, i.e. disenchantment to those who disobey and 
protection to those who obey, hence bringing two different connotations, one positive and the other negative to the same verb. This open referentiality of the verb fa?ala particularly with actions attributed to Allah deems the reference generic because we cannot limit it to the situational context of the verse. Besides, there is no textual clue that modifies the reference to a particular context or particular connotation, i.e. good vs bad.

AAL IMRAN 'The Family of Imran' 003.040

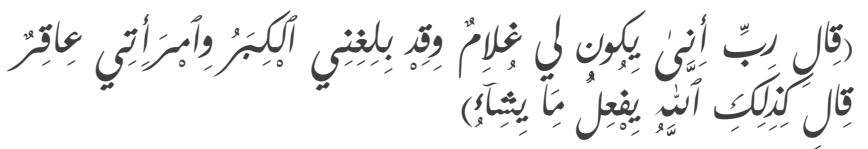

PICKTHAL: He said: My Lord! How can I have a son when age hath overtaken me already and my wife is barren? (The angel) answered: So (it will be). Allah doeth what He will.

The verb yaf?alu in this verse cannot be taken to refer to a previous verb or set of verbs because it relates to the ability of the Almighty Allah that knows no limitation. While the previous verbs express the meaning of an exclamation about a miracle ofAllah a very old man and a barren woman having a child, the verb yaf?alu here refers to Allah's ability to do whatever He will. Of course, there is some implicit reference to Allah's ability to do this particular miracle but it is quite difficult to say that the verb refers to this and only this meaning. It is generic in the sense that Allah is able to do this and any other miracle or any other action in general. According to Al Zamakhshari the verb yaf?alu refers to Allah's ability to do all miracles like this one mentioned in the verse. Generic reference does not ignore the immediate reference to a particular action described in the immediate context but it takes its full referential force from a paradigmatic reference to a much wider set of actions of which the one mentioned in the text represents only one example.

\subsection{Patterns of euphemistic reference}

The term 'euphemism' is originally a Greek term that means the use of words of good omen. Allan and Burridge (1991: 14) define euphemisms as 'alternatives to dispreferred expression, and are used to avoid possible loss of face. The dispreferred expression may be taboo, fearsome, distasteful, or for some other reason have too many negative connotations to felicitously execute speaker's communicative intention on a given occasion.' According to Farghal (1995: 366) euphemism involves 'intentional utilization

\section{Euphemistic reference of the verb fa? ala in the Holy Qur'an}
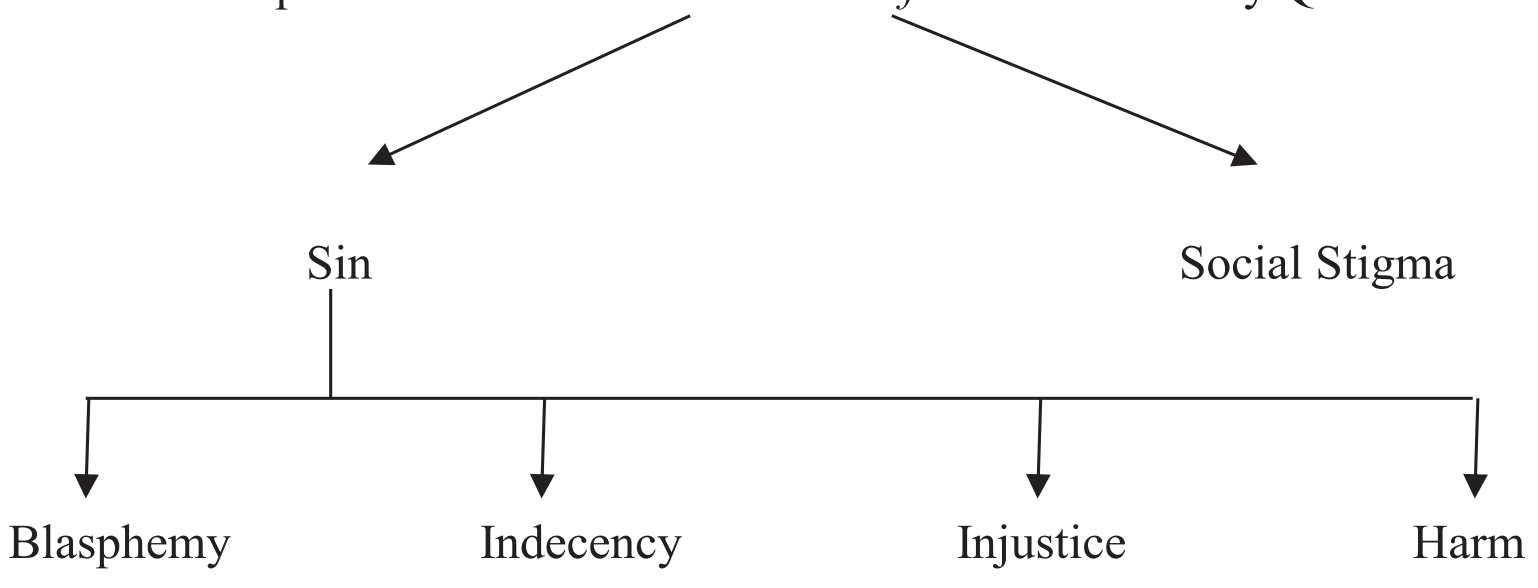

Diagram (4) The two main types and subtypes of euphemistic reference metonymy in the verb fa?ala in the Holy Qur'an 
of lexical resources in language by interactants to achieve the expression of politeness and demureness in human interaction.' This means that the main motive for euphemism is politeness. Ali (1996) points out that 'euphemism is one of the important rhetorical devices ... [i]t produces in the mind an effect that is very similar to that created by metonymy and synecdoche' (p. 23).

The Holy Qur'an is Allah's revelation to man; it is miraculous in all respects including the use of its language. Politeness is a major principle permeating all the dialogues in the Holy Qur'an and saving face is a fundamental principle in all interactions of the Holy Qur'an. Thus, it is expected that the Holy Qur'an uses euphemism not only as a mechanism of intentional substitution of offensive expressions with agreeable ones but also as a referential mechanism to refer to actions that convey some distasteful meanings.

As diagram (3) above shows the euphemistic reference of the verb fa?ala in the Holy Qur'an can be categorized into two main groups. The first is the group of expressions that relate to the notion of 'sin' in general and this includes subnotions such as 'harm', 'injustice', 'indecency' and 'blasphemy'. The other main category includes only one type which is social stigma and this is obviously less negative but still socially unacceptable.

\section{(A)Reference to sin}

This is a textual reference to a verb or action mentioned either before or after the verb fa?ala. This action expresses an act of sin or a wrong deed. This group of expressions is organized into four sub-groups: blasphemy, injustice, indecency and harm. Blasphemy covers expressions that lack reverence to Allah and those expressions that are profane and heretical. Injustice refers to a group of expressions that show some lack of fairness in dealings. Indecency refers to expressions related to obscenity or vulgarity. Harm refers to expressions referring to death, punishment, torture or killing. As usual two examples will be given to illustrate each of these sub-types and the rest of examples will be in appendix (1).

\section{(1)Reference to blasphemy}

AL-ARAAF - 007.155

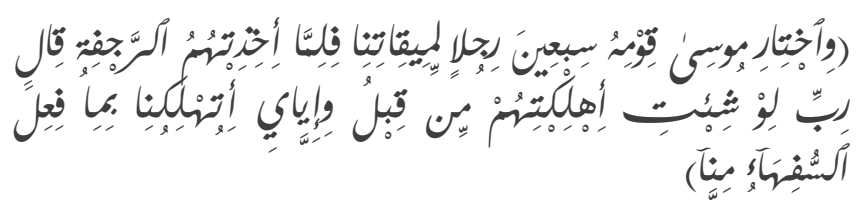

PICKTHAL: And Moses chose of his people seventy men for Our appointed tryst and, when the trembling came on them, he said: My Lord! If Thou hadst willed Thou hadst destroyed them long before, and me with them. Wilt thou destroy us for that which the ignorant among us did?

In this verse, a referential relationship is established between the verb fa?ala and the act of worshiping the golden calf mentioned three verses earlier. Here Prophet Moses is referring to the act which the ignorant among the people of Israel did. This is the act of forging a calf out of gold and worshiping it. The expression of such a blasphemous act is not repeated. Instead, it is referred to by the verb fa?ala which functions both to hide the negative aspects of the actual verb used 'calf worshiping' and to establish a textual relationship between the verb fa?ala and its referent in the Qur'anic text. This on the one hand contributes to the politeness of the Qur'anic text and on the other creates texture and cohesion and makes the verses coherent.

Another example in which the verb fa?ala is used to refer and hide a blasphemous expression is found in chapter 7.

Al-ARAAF-007.173 


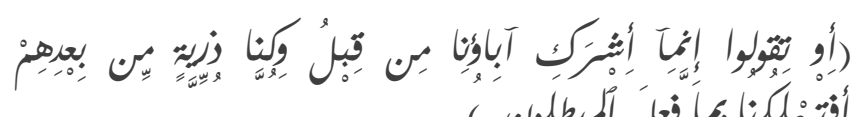

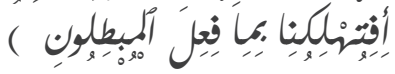

PICKTHAL: Or lest ye should say: (It is) only (that) our fathers ascribed partners to Allah of old and we were (their) seed after them. Wilt Thou destroy us on account of that which those who follow falsehood did?

Ascribing partners to Allah is a great sin and a blasphemous act. In this verse there is an explicit reference to this sin in the first half of the verse but in the second mention of this sinful act the verb fa?ala is used not only to refer to the previous mention and establish a cohesive link but also to 'cover' and 'hide' an unfavorable expression with a more neutral expression. It is the tendency of the Holy Qur'an to use euphemistic language in general (cf. Ali, 1996) but in this case the Holy Qur'an also uses euphemism as a reference, not only as a lexical choice, to refer to unfavorable actions or behaviors. The explicit mention is repeated by means of a reference mechanism through the use of the euphemistic verb fa?ala.

\section{(2)Reference to injustice}

HOOD 'Hud' - 011.087

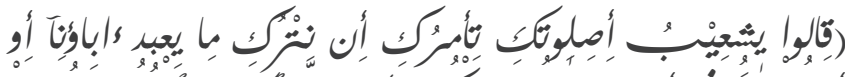

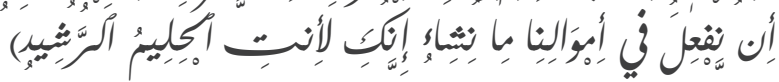

PICKTHAL: They said: O Shu'eyb! Doth thy way of prayer command thee that we should forsake that which our fathers (used to) worship, or that we (should leave off) doing what we will with our own property. Lo! thou art the mild, the guide to right behaviour.

The reference in this verse is to two main wrong acts that the people of the Prophet Shu?ayb used to do. These two acts which are referred to in the previous verse (verse 85 ) are: 'not giving full measure and full weight to people in justice, and doing wrong to people.' The people of the Prophet Shu?ayb were not dealing with people in justice. The second mention of these sinful and unjust acts is carried out through the use of the verb fa?ala because it is more neutral and hides the negative connotations of the actual verbs used to describe these actions in the previous verse.

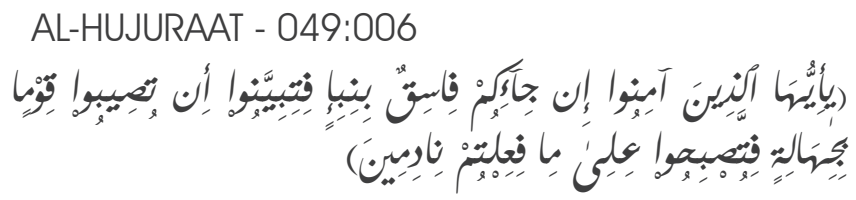

PICKTHAL: O ye who believe! If an evil-liver bring you tidings, verify it, lest ye smite some folk in ignorance and afterward repent of what ye did.

This is another example of an expression of injustice. Here it is related to slandering and libeling. The verse commands the believers to verify any news from a slanderer in order to avoid defaming people in ignorance. The second mention of this sinful deed is expressed by the use of the verb fa?ala in order to establish a textual relation and also in order to hide and cover the negative connotations of the actual verb used previously.

\section{(3)Reference to indecency}

YOUSUF - 012.032

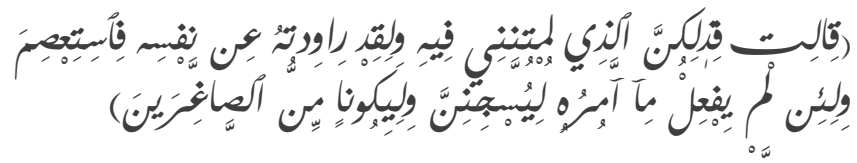

PICKTHAL: She said: This is he on whose account ye blamed me. I asked of him an evil act, but he proved continent, but if he do not my behest he verily shall be imprisoned, and verily shall be of those brought low.

The use of the verb yaf?al in this verse refers to an act of seduction that the woman was trying to do to Prophet Joseph. Here she does not want to be 
explicit about what she wanted him to do, so she used the verb fa?ala to euphemistically refer to the act of seduction. Here the euphemistic use of the verb fa?ala is explicit because it hides and at the same time refers to a series of actions that this woman wants him to do, or else he will be imprisoned or brought low. Three main functions of the verb fa?ala are evident in this verse. The first is to hide offensive expressions of sexual temptation. The second is the strong implicit and indirect referentiality to a series of actions that can be thought to belong under the category of sensual allurement. These are not mentioned in the verse but can always be imagined. The third is the pithy style which results from using coreferential devices to avoid repetition and make communication faster and comprehension smoother.

Another example of this use is in chapter 015.

AL-HIJR - 015.068-071

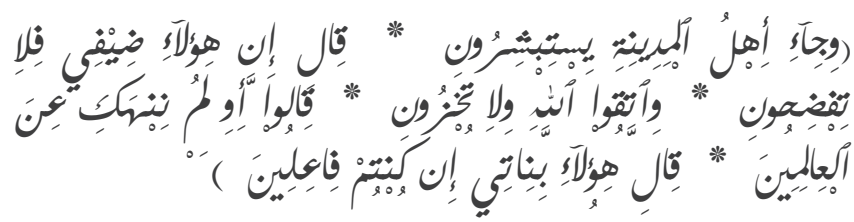

PICKTHAL: He said: Lo! they are my guests. Affront me not! And keep your duty to Allah, and shame me not! They said; Have we not forbidden you from (entertaining) anyone? He said: Here are my daughters, if ye must be doing (so).

In this verse, there is a reference to a sinful and indecent act of sodomy that the people of Prophet Lut used to do. This act is explicitly referred to in chapter $(026.165)$

PICKTHAL : What! Of all creatures do ye come unto the males, And leave the wives your Lord created for you? Nay, but ye are froward folk.

Prophet Lut says 'if you must be doing so', i.e. the lustful and sexual desire, then do it not to males among you but to my daughters (all the women in his community) in a lawful manner through the bond of holy matrimony. The use of the verb fa?ala again both establishes a cohesive relation and at the same time hides the more explicit reference to this taboo expression, i.e. sexual desire.

\section{(4)Reference to harm}

AL FAJR 'The Dawn' 089.006

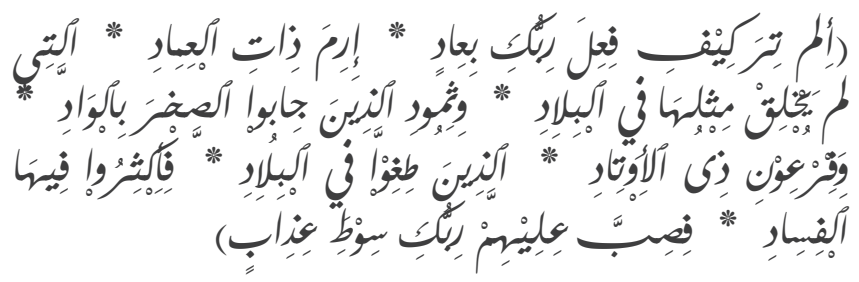

PICKTHAL: Dost thou not consider how thy Lord dealt with (the tribe of) A'ad, With many-columned Iram, The like of which was not created in the lands;

And with (the tribe of) Thamud, who clove the rocks in the valley;

And with Pharaoh, firm of might, Who (all) were rebellious (to Allah) in these lands, And multiplied iniquity therein? Therefore thy Lord poured on them the disaster of His punishment.

This is one of two examples of cataphoric reference in the entire Qur'anic text. This type of referential relation in the Qur'anic text is associated with a rhetorical question in which an answer is not sought but provided immediately afterwards. The purpose is to raise attention and create expectations on the part of the reader. In this type of verbal reference, the verb fa?ala is mentioned before the referent, thereby creating a textual relation by drawing the reader's attention and raising their expectations to what is coming next in the text, i.e. the referent of the verb fa?ala. In this example, there is a question in which the verb fa?ala is mentioned in anticipation of the actual action verb for which this representational verb is used. Although the distance between the verb fa?ala and its referent 'poured on them' 
is not small, there is clearly a forward textual relation established, creating textual cohesion between the textual elements and also textual coherence in terms of raising and fulfilling readers' expectations. This makes the reading process more interactive.

The other occurrence of a cataphoric reference is in chapter 105.

AL FIIL - 105. 001 - 005

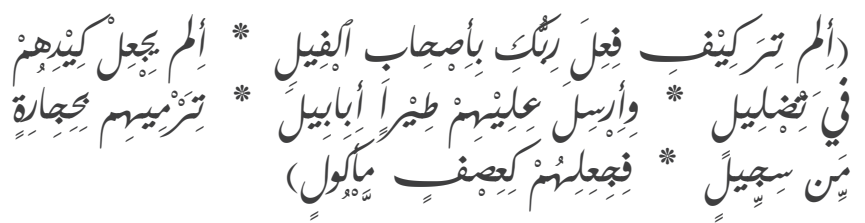

PICKTHAL: Hast thou not seen how thy Lord dealt with the owners of the Elephant?

Did He not bring their stratagem to naught, And send against them swarms of flying creatures, Which pelted them with stones of baked clay, And made them like green crops devoured (by cattle)?

Here the cataphoric relation is also evident and is associated with a question just like the example discussed above. However, the verb fa?ala here seems to refer forward to three action verbs which are in bold and underlined in the verse above. These three actions are related to some form of punishment so to refer to these actions, the verb fa?ala is used to fulfill the textual requirement of establishing a cohesive link and to euphemize rather taboo expressions referring to punishment and torture.

\section{(B)Reference to social stigma}

AL-BAQARAH - 002.234

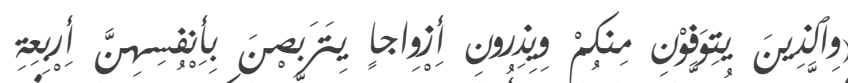

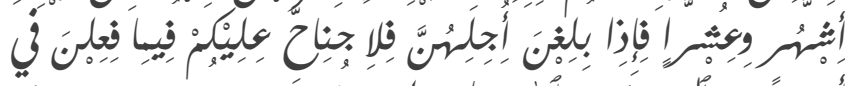

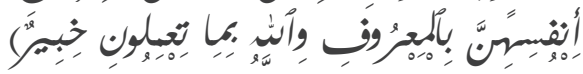

PICKTHAL: Such of you as die and leave behind them wives, they (the wives) shall wait, keeping themselves apart, four months and ten days. And when they reach the term (prescribed for them) then there is no sin for you in aught that they may do with themselves in decency. Allah is informed of what ye do.

The verb fa?ala here refers to an act that is not really sinful, blasphemous or even indecent but is somehow socially stigmatized or unacceptable. The act of a widow, after a post-mortal period of four months and ten days, seeking remarriage through meeting with suitors or even wearing colorful and attractive clothes is implicitly referred to here by the use of the verb fa?ala. These acts are lawful but might be socially stigmatized because in some communities a woman who does this after four months and ten days may be regarded unfaithful to the memory of her late husband. The verb fa?ala in this verse functions both as a euphemistic expression of these deeds and at the same time initiates a cohesive link between itself and the acts mentioned.

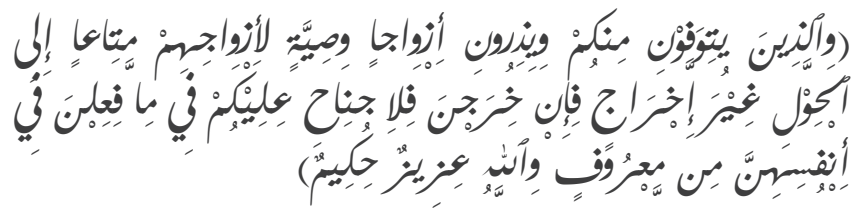

002.240

PICKTHAL: (In the case of) those of you who are about to die and leave behind them wives, they should bequeath unto their wives a provision for the year without turning them out, but if they go out (of their own accord) there is no sin for you in that which they do of themselves within their rights. Allah is Mighty, Wise.

The same kind of relationship discussed in the previous verse is also evident in this verse. Both verses address the same social phenomenon of widows who can after spending a specific period of time after the demise of their husbands, go out and seek remarriage. In this particular verse, 
the verb fa?ala specifically refers to the act of going out from home or leaving the house of the husband. This signifies the woman's willingness to accept suitors or even the woman's initiation of this kind of activity.

\section{Conclusion}

This paper investigates the metonymic function of referentiality of the verb fa?ala in the Holy Qur'an. Two major types of reference are identified: plain reference and euphemistic reference. Statistically, the euphemistic reference of the verb fa?ala in the Holy Qur'an is more pervasive than that of the plain reference. Both types of reference contribute to the textness of the Qur'anic text and more importantly to the notion of politeness in the Qur'anic text which is established through the use of positive or neutral expressions instead of direct and shocking expressions. This study has added to the notion of politeness in the Holy Qur'an a new dimension which is euphemistic reference in which the verb fa? ala is seen to function as a cover or neutral expression for other more explicit expressions related to sin, injustice, blasphemy, indecency and social stigma. 


\section{References}

Abdul Baqi, M. F. ,2004, al mo?jam al mofahras li alfaaz al Qur'an al kareem 'Indexed Dictionary of the Words of the Holy Qur'an', Beirut: Dar Al Ma?rifah

Ali, S. S. ,1996, 'Euphemism in Translation: a comparative study of euphemistic expressions in two translations of the Holy Qur'an. Turjuman 5, (1) p. 23 - 37.

Allan, K. and K. Burridge ,1991, Euphemism and Dysphemism: Language Used as Shield and Weapon. New York: Oxford University Press

Al-Sharafi, Abdul Gabbar ,2004, Textual Metonymy: a semiotic approach, London: Macmillan.

Al- Zabeedi, M. M. Taaj Al Aroos min Jawahir Al Qamoos "The Crown of the Bride from the Jewels of the Dictionary" edited by lbrahim, A. K. \& Mahmoud, K. S. M. ,2007, Beirut: Daar al-kutub al-ilmiyyah.

Al-Zamakhshari, M. A. Al-Kashshaaf references downloaded from the website of Royal Aal Al-Bayt Institute for Islamic Thought, at http://www. altafsir.com retrieved November 5th, 2012.

Croft, W. , 1993, 'The role of domains in the interpretation of metaphors and metonymies'. Cognitive Linguistics, 4-4, 335-370.

Dressler, W. , 1977, (ed.) Current Trends in Textlinguistics. Berlin: Walter de Gruyter.

Farghal, M. ,1995, 'Euphemism in Arabic: a Gricean Interpretation. Anthropological Linguistics, 37, no. 3, pp. 366-368.

Fauconnier, Gilles ,1985, Mental Spaces: Aspects of Meaning Construction in Natural Language. Cambridge, Mass.: MIT Press.

Fauconnier, G. and M. Turner ,2002, The Way We Think : Conceptual Blending and the Mind's Hidden Complexities. New York: Basic Books.

Grice, P. ,1975, 'Logic and Conversation'. In P. Cole \& J. Morgan (eds.) Syntax and Semantics, vol. 3. Speech acts. New York: Academic Press.

Halliday, M. A. K. and R. Hassan ,1976, Cohesion in English, London: Longman

Harweg, R. , 1977, 'Substitutional textlinguistics', in W. Dressler, pp. 247-260.

Ibn Manzour Lisaan Al Arab. (The Arab Tongue), edited by Abdul Wahab, A. M. and M. Al Ubaidy (1999). Beirut: Arab Heritage Revival Establishment

Jakobson, R. ,1971, 'Two Aspects of Language and Two Types of Aphasic Disturbances'. In Jakobson, R. and M. Halle (eds.) Fundamentals of Language. The Hague: Mouton.

Khattäbi, M. ,1991, Lisäniyyät al-Nass: Madkhal 'ila 'Insijäm al-Khitäb. Beirut: Al-Markaz al-Thaqäfi al'Arabi.

Lakoff, G. and Johnson, M. ,1980, Metaphors We Live By. Chicago: The University of Chicago Press. Lakoff, G. ,1987, Women, fire and dangerous things: what categories reveal about the mind. Chicago: Chicago University Press.

Panther, K-U and G. Radden , 1999, (eds.) Metonymy in Language and Thought. Amsterdam: Benjamins. Pickthal, M. The Meaning of the Glorious Qur'an: an English translation. References downloaded from the website of Royal Aal Al-Bayt Institute for Islamic Thought, at http://www.altafsir.com retrieved on November 5th, 2012.

Royal Aal al-Bayt Institute for Islamic Thought, an encyclopedic website that contains translations, 
several interpretations and a number of other online services related to the Holy Qur'an, at http://www. altafsir.com.

Saussure, F. de ,1983, Course in General Linguistics (translated and annotated by Roy Harris). London: Duckworth.

Stirling, L. ,1996, 'Metonymy and Anaphora'. Belgian Journal of Linguistics, 10: 69-88. 